\title{
Malay world in the Kasih Bonda Kampung Paya Kami poetry collection
}

\begin{abstract}
Siti Zainon Ismail is an author, a Malay cultural heritage researcher, an artist, a poet, a Malaysian painter, and the 14th Malaysian National Laureate. She produced many books of poetry. However, in this study, a book of poetry entitled Kasih Bonda Kampung Paya Kami was used as study material. The objective of this study was to identify and analyze the Malay world contained in this poetry collection. The approach of Poetics of Malay Literature by Muhammad Haji Salleh served as the basis of the study. The findings showed that first, the Malay world can be seen from a Malay house architechture that had the elements of creativity and inventiveness. Second, the customs of Malay family. In this case, the community was educated and behaved in accordance with the Malay customs such as the tradition to celebrate the birth and the purification. Third, the family economic aspect which was associated with the community's humble occupation the at that time.through the most dominant multimedia and can be applied by the parties involved.
\end{abstract}

Keyword: Technology; Interactivity; MonkeySurvey; Technology Accaptence Model (TAM) 